\title{
Angażowanie użytkowników w proces projektowania stron internetowych i aplikacji mobilnych za pomocą platform crowdsourcingowych ${ }^{1}$
}

\author{
Andrzej Gil
}

\begin{abstract}
Abstrakt
Cel/Teza: Celem artykułu jest analiza i omówienie dostępnych narzędzi crowdsourcingowych używanych na poszczególnych etapach procesu projektowego stron internetowych i aplikacji mobilnych. Praca stanowi omówienie i opracowanie dostępnych metod angażowania użytkownika i sygnalizuje efekty wynikające z takiej współpracy.

Koncepcja i metody badawcze: Ze względu na dynamiczny rozwój samego crowdsourcingu, poszczególne techniki angażowania użytkowników zostały zebrane przez autora na podstawie kompleksowej analizy piśmiennictwa naukowego i branżowego ( $\mathrm{w}$ tym serwisów internetowych dla praktyków dziedzinowych), podręczników oraz raportów komercyjnych. Platformy crowdsourcingowe wykorzystywane $\mathrm{w}$ procesie projektowania, ze względu na swój praktyczny charakter, zostały ponadto opatrzone przykładami implementacji, w celu lepszego wyjaśnienia ich funkcjonowania.

Wyniki i wnioski: Dostępne platformy crowdsourcingowe obecne są na każdym z etapów projektowania aplikacji mobilnych i stron internetowych - stanowią kopalnię pomysłów i opłacalne rozwiązanie z ekonomicznego punktu widzenia. W większości koncentrują się one tylko na podsuwaniu nieustrukturyzowanych sugestii i walidacji wdrożonych już rozwiązań. Crowdsourcing w niewielkim stopniu wykorzystuje się przy faktycznym budowaniu narzędzi cyfrowych. Autor zlokalizował jednak, istniejące już teraz przykłady angażowania użytkowników w proces projektowania produktów i usług cyfrowych, które w najbliższej przyszłości mogą przeobrazić się w rozwiązania crowdsourcingowe. Oryginalność/Wartość poznawcza: Zgodnie z wiedzą autora, przedstawiony temat nie był jeszcze opracowany w piśmiennictwie zarówno polskim, jak i międzynarodowym. Artykuł jest pierwszą próbą holistycznej analizy i sklasyfikowania poszczególnych narzędzi crowdsourcingowych wykorzystywanych w praktyce projektowania produktów i usług cyfrowych.
\end{abstract}

\section{Słowa kluczowe}

Aplikacje mobilne. Crowdsourcing. Customer engagement. Proces projektowy. Platformy crowdsourcingowe. Serwisy informacyjne. Strony internetowe. User centered design. Zaangażowanie użytkownika.

Otrzymany: 5 sierpnia 2021. Zrecenzowany: 9 września 2021. Poprawiony: 18 października 2021. Zaakceptowany: 6 listopada 2021.

1 Artykuł został napisany na podstawie pracy dyplomowej autora pod tytułem Crowdsourcing w procesie projektowania serwisów informacyjnych i aplikacji mobilnych, napisanej pod opieką prof. dr hab. Barbary Sosińskiej-Kalaty na studiach I stopnia na kierunku Architektura przestrzeni informacyjnych na Wydziale Dziennikarstwa, Informacji i Bibliologii Uniwersytetu Warszawskiego. 


\section{Wprowadzenie}

Crowdsourcing jest stosunkowo nową koncepcją obejmującą cały zespół praktyk współpracy twórców z użytkownikami odbywającej się za pomocą Internetu, której ramy, ze względu na proliferację zjawiska, nie są ściśle wyznaczone i dochodzi do zacierania się granic pojęcia (Estellés \& González, 2012). Często jest ono utożsamiane z terminami takimi jak: mądrość tłumów, współtworzenie wartości z klientem, aktywność użytkowników w sieci, produkcja partnerska czy otwarta innowacja (Kowalska, 2015).

Ugruntowało się przekonanie, że crowdsourcing jest efektywnym sposobem wyszukiwania oraz uzyskiwania dostępu do wiedzy i umiejętności od szerokiego spektrum użytkowników, który można zastosować do rozwiązywania stosunkowo prostych i dobrze zdefiniowanych problemów (Afuah \& Tucci, 2012; Mount et al., 2020). Bardziej rozbudowane definicje wskazują również na dobrowolność i elastyczność rekrutacji do współpracy przy wykonywanym zadaniu poprzez tzw. open call (otwarte zapytanie, ogłoszenie), które mogą proponować osoby indywidualne, instytucje, organizacje non-profit, czy przedsiębiorstwa (Estellés \& González, 2012).

W ostatnich latach, wraz z nasileniem popularyzacji zjawiska, rozszerza się definicję crowdsourcingu, zwracając uwagę na fakt angażowania się użytkowników w interakcję (konkurencję, wymianę czy współpracę), co pozwala łączyć pomysły, tworząc rozwiązania inkluzywne (Mount et al., 2020). Zadania nie są przypisywane wąskiej grupie wyspecjalizowanych ekspertów w danej dziedzinie, ale dużej liczbie odpowiednio rekrutowanych nieprofesjonalistów (McAllister Byun et al., 2015), którzy mogą ograniczać się do specjalnie dobranej społeczności. Propozycja partycypacji w pewnych zadaniach może być też kierowana do ogółu (Majchrzak \& Malhotra, 2013). Przed zainteresowanymi użytkownikami stawiane są zadania o różnym stopniu złożoności (Estellés \& González, 2012). Każdy z nich wnosi pewien wkład - pracę, wiedzę, doświadczenie czy środki finansowe, które gratyfikowane są stosownym wynagrodzeniem oraz satysfakcją - ekonomiczną, uznania społecznego, samooceną albo rozwojem własnych umiejętności (Estellés \& González, 2012).

Trzecim komponentem projektu crowdsourcingowego, obok podmiotu inicjującego działanie i „tłumu”, do którego kieruje on zapytanie, jest odpowiednia infrastruktura (Kowalska, 2015), bez której nie byłoby możliwe tworzenie sieci powiązań między uczestnikami oraz narzędzi do dzielenia się pomysłami (Majchrzak \& Malhotra, 2013). Mowa o platformach crowdsourcingowych - technicznych i organizacyjnych narzędziach do zarządzania i utrzymania powstającej społeczności oraz definiowania interakcji między crowdsoucerami i użytkownikami (Blohm et al., 2018). Ze względu na kryteria różnorodności wkładu wnoszonego przez partycypujących w projekcie i stopnia agregacji wkładu użytkowników przez moderatora (crowdsourcera), platformy crowdsourcingowe można podzielić na cztery typy:

- mikrozadaniowe (ang. microtasking) ${ }^{2}$ - charakteryzuje je właściwie jednakowy wkład pracy użytkowników w odgórnie ustalonych, prostych zadaniach (czasem cyklicznych); używane są do przetwarzania prostych, powtarzalnych zadań z ustrukturyzowanymi danymi wejściowymi;

\footnotetext{
${ }^{2}$ Nazwy typów platform tutaj i w kolejnych punktach w tłumaczeniu własnym autora.
} 
- zbierające informacje (ang. information pooling) - addytywnie agregują rozproszone informacje od użytkowników (takie jak opnie, oceny); używane do pozyskiwania i weryfikowania potrzeb klientów, prognozowania, zbierania informacji o położeniu;

- poszukujące rozproszonych informacji (ang. broadcast search) - zbierają alternatywne rozwiązania danego problemu od różnych użytkowników, z których wybierane są najbardziej obiecujące; używane do uzyskiwania różnorodnych punktów widzenia na dane zadanie;

- otwartej współpracy (ang. open collaboration) - ograniczony indywidualny wkład uczestników jest agregowany poprzez kooperację współtwórców; używane są do tworzenia złożonych produktów, które wymagają integracji rozproszonej wiedzy i umiejętności (Blohm et al., 2018).

W literaturze wymieniane są dwie podstawowe funkcje, które platformy powinny spełniać. Pierwszą z nich jest zarządzanie „pracownikami”, które pozwala na rekrutację użytkowników według określonych kryteriów, filtrowanie i angażowanie do poszczególnych zadań. Drugą podstawową funkcją platformy jest zarządzanie zadaniami, które pozwala na dystrybucję zadań wśród pracowników i zbieranie efektów ich pracy (Assis Neto \& Santos, 2018).

Artykuł stanowi rozważania na temat faktycznej roli crowdsourcingu i platform crowdsourcingowych w procesie projektowym oraz jest próbą klasyfikacji tychże platform i umiejscowienia ich na linii relacji twórcy z użytkownikiem. W tym celu autor zebrał i omówił dostępne i używane obecnie techniki angażujące użytkowników oraz ich praktyczne zastosowanie $\mathrm{w}$ procesie tworzenia oprogramowania w postaci platform crowdsourcingowych. Ponadto rozważania objęły motywacje skłaniające odbiorców do współpracy na poszczególnych etapach projektowania i twórców do sięgnięcia po pomoc „tłumu” oraz wynikające $\mathrm{z}$ tego implikacje. Istotny obszar angażowania użytkowników w prace projektowe stanowią także badania użytkowników. Jednak ze względu na swoją rozległość, temat ten nie został zawarty w poniższym artykule, $\mathrm{w}$ którym w centrum analizowanego zagadnienia została umieszczona interakcja twórców z użytkownikami za pomocą platform crowdsourcingowych. Autor podjął jednak temat trzech typów badań użytkowników sensu stricto, które w intensywny sposób czerpią z oprogramowania do osiągnięcia właściwych celów, zbieżnych z problematyką artykułu. Poszczególne techniki i platformy crowdsourcingowe zostały zebrane przez autora na podstawie analizy piśmiennictwa naukowego, branżowego (w tym serwisów internetowych dla praktyków dziedzinowych), podręczników oraz raportów komercyjnych. Obrana metoda badawcza objęła analizę literatury z obszarów: user experience (UX, wrażeń użytkowników), interakcji człowieka z komputerem, informatyki, nauki o informacji, socjologii, marketingu oraz zarządzania. Techniki angażowania użytkowników wykorzystywane w procesie projektowym, ze względu na swój praktyczny charakter, zostały ponadto opatrzone przykładami implementacji.

Artykuł został podzielony na trzy części, które odzwierciedlają etapy procesu projektowania i wdrażania aplikacji mobilnych i serwisów informacyjnych. Schemat organizacji tego procesu został zaczerpnięty z ogólnego modelu informatycznego procesu projektowego (Lawrence \& Schneider, 2018; Phyo, 2003; Sacha, 2014) i odpowiednio zmodyfikowany przez autora dla wyeksponowania etapów, w których dochodzi do interakcji projektantów z użytkownikami. Są to:

(1) ideacja i prototypowanie;

(2) walidacja i testowanie;

(3) wdrożenie i dalszy rozwój. 
Poza wymienionymi wyżej, w procesie projektowania wyodrębnia się także etapy wstępne, takie jak: określanie wymagań i projektowanie założeń systemu (Phyo, 2003; Sacha, 2014). Jednak z racji braku zaangażowania użytkowników przez twórców na tychże etapach projektowania nie są one przedmiotem niniejszego opracowania.

\section{Crowdsourcing na etapie ideacji i prototypowania}

Pierwszym z wyodrębnionych etapów projektowania, na którym twórcy mogą angażować użytkowników i crowdsourcować część zadań, jest faza ideacji i prototypowania. W tej fazie są realizowane procesy generowania, dookreślania i testowania pomysłów na finalny produkt (Lawrence \& Schneider, 2018), walidacji wstępnych założeń serwisu lub aplikacji oraz ich późniejszego prototypowania. Prototypowanie polega na projektowaniu rozwiązań, które zgodnie z wybranymi pomysłami i przyjętymi założeniami powinny zaspokoić potrzeby przyszłych odbiorców (Badura, 2019). Na tym etapie zestawia się pomysły z rzeczywistością i weryfikuje założenia na temat danego produktu. Korzystanie z crowdsourcingu jest tutaj zarówno sposobem szybkiej oceny projektowanych rozwiązań, środkiem komunikacji z przyszłym użytkownikiem, jak i metodą prezentacji odbiorcom najważniejszych cech projektu (Lawrence \& Schneider, 2018).

\subsection{Sortowanie kart}

Jedną z często stosowanych form crowdsourcingowego zaangażowania na etapie ideacji i prototypowania jest pomoc przy tworzeniu logicznej struktury organizacji treści wewnątrz serwisu, tj. taksonomii. Wykształciła się tutaj metoda etykietowania zawartości i porządkowania etykiet w pewnym układzie hierarchicznym, zwana sortowaniem kart. Wyróżnia się dwa główne typy sortowania kart, które można również wykorzystywać komplementarnie:

- $\quad$ sortowanie otwarte: użytkownicy samodzielnie etykietują zawartość i dzielą ją na samodzielnie tworzone kategorie ogólniejsze;

- $\quad$ sortowanie zamknięte: użytkownicy przyporządkowują etykiety do odgórnie wyznaczonych kategorii (Rosenfeld et al., 2017).

Pierwszą metodę wykorzystuje się w celu odkrywania modeli mentalnych ${ }^{3}$ użytkowników i ich spojrzenia na treści zamieszczone w serwisie. Druga pozwala zweryfikować percepcję przyszłych użytkowników - pokazać, jak użytkownicy rozumieją dane kategorie, czy są właściwe i jednoznaczne oraz, w których z nich spodziewają się odnaleźć dane treści (Mościchowska \& Rogoś-Turek, 2018).

Oba z powyższych typów sortowania kart mogą być realizowane zarówno indywidualnie, jak i jako praca zespołowa. Przy podejściu indywidualnym występuje problem z agregacją i odwzorowaniem wyników poszczególnych użytkowników. Przy podejściu grupowym decyzyjność powierzona jest grupie i realizowana za pomocą konsensusu. Dzięki niej twórcy są zwalniani z interpretacji indywidualnych wyników, zaś partycypujący mają poczucie satysfakcji oraz wspólnego wkładu w przyszłe rozwiązania (Sikorski, 2010).

\footnotetext{
${ }^{3}$ Model mentalny - pojęcie oznaczające zespół założeń, wartości, przekonań czy stereotypów charakteryzujących sposób postrzegania i rozumienia przez kogoś świata, np. rozumienia jak działają poszczególne rzeczy.
} 
Metoda sortowania kart jest również pomocna dla twórców, gdy mają oni do czynienia z danymi dziedzinowymi (z różnymi kontekstami znaczeniowymi) oraz w przypadku, gdy danych, etykiet lub kategorii jest relatywnie dużo (Mościchowska \& Rogoś-Turek, 2018). Przykładową platformą stworzoną do tego typu badań jest Optimal Workshop. Pozwala ona, oprócz wstępnej organizacji taksonomii poprzez sortowanie kart (Rys. 1 i 2), również na późniejszą walidację wyników za pomocą krótkich ankiet.

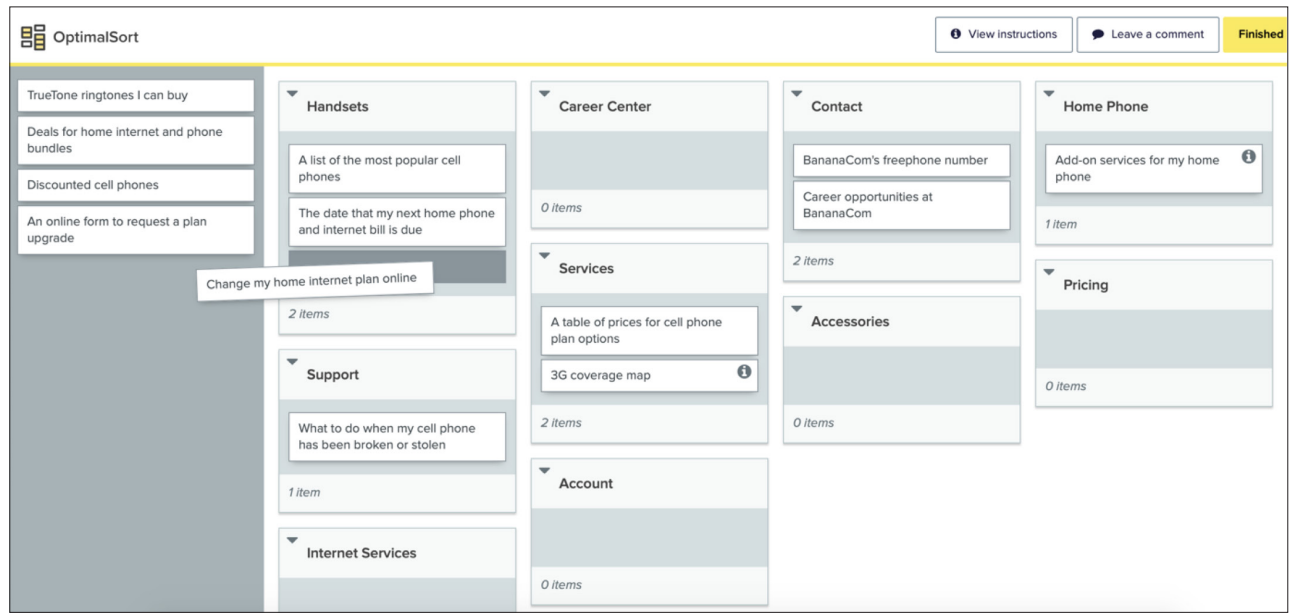

Rys. 1. Optimal Workshop: sortowanie zamknięte (źródło: Optimal Sort https://bananacom.optimalworkshop.com/optimalsort/bananacom-demo-survey-closed, dostęp: 20.03.2021)

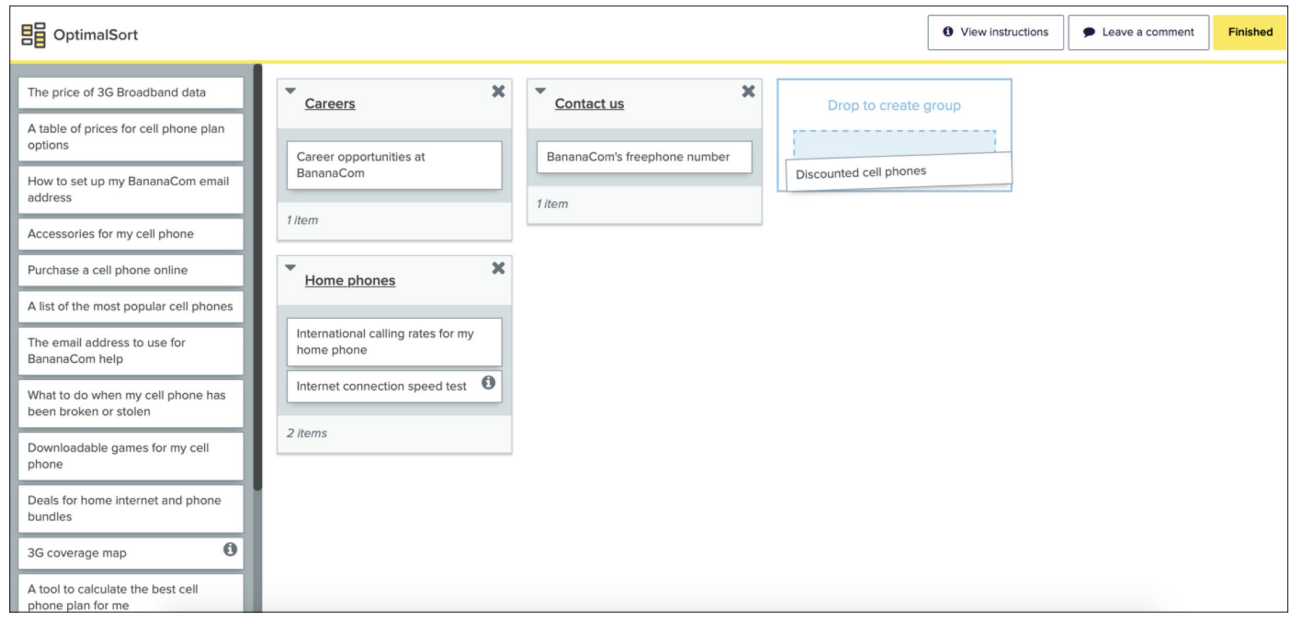

Rys. 2. Optimal Workshop: sortowanie otwarte (źródło: Optimal Sort https://bananacom.optimalworkshop.com/optimalsort/bananacom-demo-survey-open, dostęp: 20.03.2021) 


\subsection{Tagowanie zasobów}

Oprócz kategoryzowania, użytkownicy mogą zostać zaangażowani również do tworzenia folksonomii, czyli społecznego indeksowania zasobów za pomocą tagów. Zadanie to opiera się na stworzeniu przez użytkowników nieustrukturyzowanego zbioru terminów (słów kluczowych, tagów) opisujących wybrany zasób (produkt, dokument, zdjęcie, film, multimedium itp.). Terminy mogą być tworzone przez użytkowników lub wybierane ze słownictwa kontrolowanego. Na przykład mogą one opisywać zarówno treść dokumentu, jak i subiektywne odczucia na jego temat (Roszkowski, 2007). Popularnym serwisem korzystającym z funkcji tagowania jest Flickr, który pozwala na tagowanie dowolnych zdjęć w celu identyfikacji ich zawartości. Ponadto umożliwia oznaczanie osób przedstawionych na zdjęciu na podstawie wyboru terminów z listy rozwijanej. Swoistą wersją tagów mogą być również opinie o konkretnych produktach w sklepach internetowych, np. na portalu Allegro (Allegro Pomoc, n.d.), które dokładniej zostaną omówione w dalszej części artykułu.

Badanie przeprowadzone przez Bar-Ilan, Zhitomirskego-Geffeta, Millera i Shohamę (2013) sygnalizuje, że tagowanie przez ekspertów dziedzinowych zazwyczaj jest zbyt wąskie i specjalistyczne dla zwykłych użytkowników. Z drugiej strony, treści opisywane przez użytkowników mogą cechować się nieprzewidywalnością oraz powierzchownością (Keyser, 2012). Ponadto użytkownicy zazwyczaj funkcjonują w pewnym kontekście, na ich decyzje wpływają czynniki wewnętrzne i zewnętrzne oraz nie posiadają oni odpowiednich kwalifikacji. Badanie Bar-Ilan et al., (2013) pokazuje jednak, że deficyt specjalistycznej wiedzy może zostać zrekompensowany poprzez dyskusję z innymi użytkownikami („mądrość tłumów”) lub informację podstawową o danym zasobie podaną przed jego tagowaniem. Dzięki wyżej wymienionym czynnikom, użytkownicy sami są w stanie stworzyć dokładny i relewantny zestaw tagów, który pozwala na efektywne przeszukiwanie i nawigację wewnątrz kolekcji (Rosenfeld et al., 2017) oraz pomaga w podjęciu wyboru konkretnych produktów na podstawie opinii innych użytkowników (Roszkowski, 2007).

\subsection{Crowdfunding}

Oprócz opisywania tworzonej treści i walidowania własnych pomysłów, twórcy aplikacji mobilnych i serwisów internetowych mogą również zwrócić się do użytkowników o środki na realizację swojego pomysłu. Crowdfunding jest alternatywą dla poszukiwania sponsorów i inwestorów. Zakłada formę finansowania opartą na dużej liczbie stosunkowo niewielkich wpłat od prywatnych donatorów. W zamian za uzyskane przychody, twórcy oferują nagrodę (ang. reward-based crowdsourcing) albo udział w zyskach (ang. equity-based) (Yasar, 2021). Popularność zyskuje również trzeci typ crowdfundingu - polegający jedynie na dobrowolnym przekazaniu wpłaty (ang. donation-based) (Zhang et al., 2020). Zbiórkę można przeprowadzić za pomocą specjalnie do tego stworzonych platform crowdfundingowych, które umożliwiają interakcję między użytkownikami. Największymi są Kickstarter i IndieGoGo, zaś na polskim rynku Wspieram.to i PolakPotrafi (Dzikowska, 2016). Twórca, który chce zebrać fundusze, rozpoczyna kampanię, umożliwiając chętnym wpłatę za pośrednictwem wybranej platformy w danym czasie.

Dotacja w ramach crowdfundingu nie musi być jednorazowa. Na przykład w modelu wielokrotnych donacji działa brytyjski start-up Beeline - producent nawigacji rowerowej 
opartej na kompasie. Firma ta o wsparcie dla projektu poprosiła miłośników kolarstwa pierwszy raz w 2015 r. za pomocą platformy Kickstarter. Z zakładanych 60 tys. funtów udało się jej wówczas uzyskać na wsparcie projektu ponad 150 tys. funtów, czyli około 250\% zakładanego celu finansowego. Wpłaty dokonało ponad trzy tys. użytkowników, którzy za pomocą platformy mogli dyskutować między sobą oraz z twórcami na temat wyglądu docelowego produktu i jego funkcjonalności (Rys. 3). Dzięki możliwościom platformy twórcy mogli również publikować aktualizacje projektu, w których ustosunkowywali się do sugestii darczyńców oraz rozdysponowywać nagrody w postaci progów osiąganych w zależności od wysokości donacji (Kickstarter, 2015). Firma zorganizowała także kampanię crowdfundingową na platformie Seedrs, aby sfinansować rozwój sprzedaży detalicznej i łańcucha dostaw. Tym razem sięgnięto po finansowanie udziałowe (PitchBook, n.d.), a więc inwestujący otrzymali część udziałów spółki. Ta kampania również zakończyła się sukcesem i zebraniem ponad 110 tys. funtów od 285 donatorów na dalszy rozwój firmy (Seedrs, 2017).

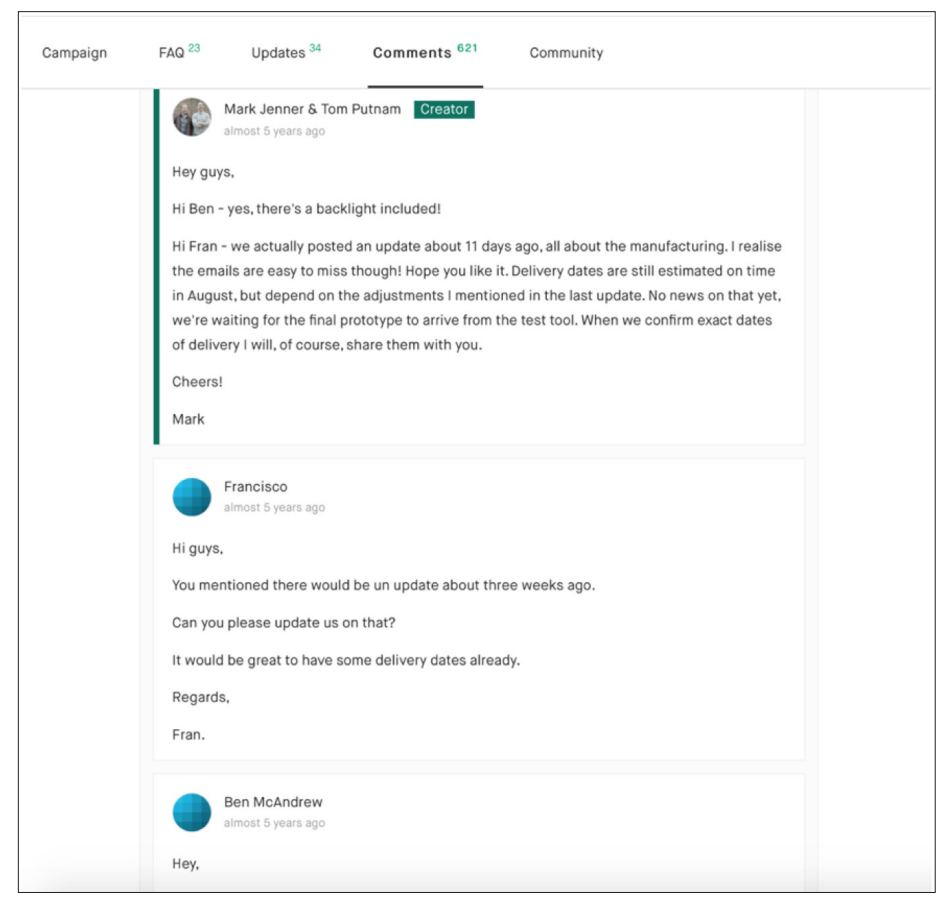

Rys. 3. Forum na portalu crowdfundingowym, na którym użytkownicy mogą dzielić się pomysłami z twórcami (źródło: Kickstarter https://www.kickstarter.com/projects/ridebeeline/ beeline-smart-navigation-for-bicycles-made-simple/comments, dostęp: 15.04.2021)

Jednak, poza przypadkiem firmy Beeline, generalnie wskaźniki sukcesu na platformach crowdfundingowych nadal są niskie (Tan \& Reddy, 2021). Wśród czynników, które powinny spełniać ogłoszenia na platformach crowdfundingowych, aby wzbudzać zaufanie i realizować zakładane cele, wymieniana jest przede wszystkim jakość zamieszczanych informacji. Powinny one być dokładnie i kompletne. Główne cele zbiórki powinny zostać dokładnie opisane, opatrzone dokumentacją zdjęciową lub filmową i referencjami zaufanych 
organizacji (Zhang et al., 2020). Projekt i informacje o zbiórce powinny być również regularnie aktualizowane (YLAI, 2016).

Drugim czynnikiem jest bezpieczeństwo samej platformy i reputacja. Część użytkowników nie ma żadnego wcześniejszego doświadczenia z crowdfundingiem i obawia się kradzieży (Niedzielska, 2017), więc platforma powinna również spełniać rolę przewodnika po procesie donacji (Zhang et al., 2020).

Trzecim czynnikiem, opisywanym w piśmiennictwie dotyczącym crowdfundingu, jest tworzenie poczucia wspólnoty. Wyznacznikiem sukcesu kampanii crowdfundingowej jest to, jak blisko darczyńcy współpracują z osobami ubiegającymi się o pozyskanie funduszy w kampaniach crowdfundingowych. Donatorzy chętniej będą wspierać zbiórkę, gdy organizatorzy regularnie informować będą o postępach i wytworzą poczucie, że każda, nawet najmniejsza wpłata ma sens w kontekście całego projektu (Tan \& Reddy, 2021; Zhang et al., 2020). Inne badania wskazują również, że długotrwałość relacji na linii twórca zbiórki donatorzy (np. za pomocą mediów społecznościowych) ma kluczowy wpływ na poczucie zaufania i możliwość współpracy prosumenckiej (Gerber et al., 2012).

\subsection{Ustalanie wysokości opłat}

Oprócz finansowania wprost, twórcy mogą zwrócić się do klientów o pomoc w wyborze najbardziej optymalnego sposobu pobierania opłat na rozwój samej aplikacji lub strony internetowej. Obecnie wyodrębnia się kilka metod finansowania. Są to m.in.: reklamy, jednokrotne płatności za dostęp oraz modele subskrypcyjne. Gdy twórca zdecyduje się na model darmowej aplikacji z reklamami, ważne jest, aby poznać kim jest grupa docelowa aplikacji i umieszczać jedynie takie treści reklamowe, które odzwierciedlają jej spektrum zainteresowań (Shapiro \& Varian, 2007). W przeciwnym razie reklamy mogą powodować niechęć ze strony odbiorców. W przypadku aplikacji „płatnych” użytkownik obowiązany jest do opłacenia z góry dostępu do całej treści, bez wcześniejszego sprawdzenia, jak działa aplikacja. Takie rozwiązanie uważane jest za niekorzystne dla klienta, toteż wypracowano modele płatności, które pozwalają zapoznać się użytkownikowi z aplikacją, zanim dokona on opłaty. Pośród nich można wyróżnić kilka głównych:

- $\quad$ klasyczna subskrypcja - dostęp do treści powiązany jest z cyklicznym pobieraniem opłat od użytkownika. W tym modelu często występuje kliku- lub kilkunastodniowy "okres próbny”, w czasie którego opłata nie jest pobierana, a użytkownik zyskuje czas, aby zapoznać się z narzędziem. W takim modelu funkcjonują np. muzyczne serwisy streamingowe czy platformy VoD;

- freemium - dostęp do podstawowych narzędzi jest darmowy, jednak pewna część funkcjonalności wewnątrz aplikacji jest zablokowana. To użytkownik decyduje, za które z nich chce zapłacić. Taki model funkcjonuje np. w grach mobilnych (gdzie odblokowuje się dostęp do dodatkowych poziomów czy przyspiesza procesy zachodzące wewnątrz rozgrywki), aplikacjach typu fitness (gdzie pozwala odblokowywać nowe rodzaje treningów) i aplikacjach biurowych (do zwiększania pojemności dyskowej);

- paymium - użytkownik płaci podstawowy dostęp do serwisu, jednak, podobnie jak w modelu freemium, część funkcjonalności jest dodatkowo płatna. Model ten jest używany np. w grach mobilnych - gdzie dodatkowa opłata także odblokowuje dodatkową zawartość (MindSea, 2020). 
Forma opłaty nie musi być również stała i jednakowa dla wszystkich użytkowników. Twórcy mogą ją różnicować oraz dostosowywać model subskrypcyjny do konkretnej grupy użytkowników, według ich nawyków i potrzeb (Shapiro \& Varian, 2007).

O wybór strategii zapytali użytkowników twórcy aplikacji sportowej Forza Football. W specjalnie utworzonej ankiecie pytano zarówno o to, w jakim modelu cenowym aplikacja miałaby funkcjonować, jak i o formę i umiejscowienie ewentualnych banerów reklamowych. Wszystko po to, ażeby jak najmniej ingerowały one w użyteczność i przejrzystość aplikacji dla użytkowników, którzy zdecydują się nie przechodzić na wersję płatną. Po konsultacji zdecydowano się na model subskrypcyjny wraz z zachowaniem darmowej wersji z reklamami. Wersję płatną nazwano „Forza Legend” i zawarto w niej rozszerzoną funkcjonalność aplikacji (App Store Preview, n.d.). Darmowa wersja została okrojona z widoku „aktualności piłkarskich" i, na podstawie ankiety, przygotowano dla niej specjalne pozycje dla banerów reklamowych (Rys. 4) (Forza Football, n.d.).

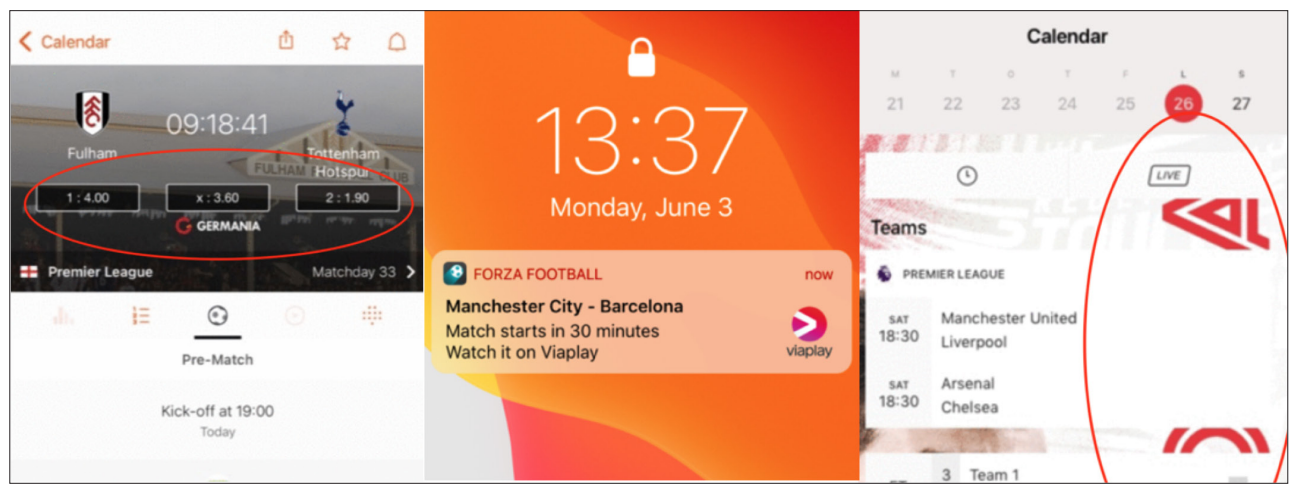

Rys. 4. Podstrony aplikacji Forza Football. Przykłady pozycji banerów reklamowych konsultowanych z użytkownikami: kurs bukmacherski w widoku meczu, dodatki do powiadomień push, tło z banerem reklamowym (źródło: Forza Football Advertising https://forzafootball.com/company/advertising/, dostęp: 2.05.2021)

\section{Crowdsourcing na etapie walidacji i testowania}

Po wypracowaniu wstępnego projektu przyszłego produktu, kolejnym krokiem w procesie rozwoju projektu jest implementacja rezultatów osiągniętych na pierwszym etapie w postaci wytworzenia sekwencji wyrażeń języka programowania - kodu źródłowego aplikacji (Krętowski, n.d.) oraz późniejsza walidacja zastosowanych rozwiązań. Walidacja i testowanie obejmuje przejście od eksperymentowania do budowy faktycznego produktu (Lawrence \& Schneider, 2018). Na tym etapie procesu projektowania zaangażowanie użytkowników może polegać na testowaniu gotowej lub prawie gotowej wersji aplikacji (tzw. builda) oraz na udziale w badaniach interakcji odbiorcy z produktem celem poznania kontekstu, w jakim będą wspólnie funkcjonować. 


\subsection{Wspótczesny „eye-tracking”}

Jedną z popularnych metod wykorzystywanych przy okazji testów użyteczności z wykorzystaniem przyszłych użytkowników jest eye-tracking, czyli okulografia. Polega ona na rejestracji za pomocą okulografu ruchów gałki ocznej - miejsca skupienia wzroku i ruchu. Pozwala na sprawdzenie, gdzie i jak długo patrzy osoba badana. W kontekście stron internetowych i aplikacji mobilnych mogą to być poszczególne elementy interfejsu, np. obrazy, przyciski, komponenty menu. Można również dowiedzieć się, gdzie użytkownik w ogóle nie patrzy i na co nie zwraca uwagi, ile czasu mija między kolejnymi kliknięciami i gdzie pojawiają się konfuzje związane z systemem (Klaib et al., 2021).

Eye-tracking uważany jest za pomiar obiektywny w tym sensie, że opiera się na bezpośredniej rejestracji reakcji uczestników badania, a nie na subiektywnych deklaracjach osób badanych (Mościchowska \& Rogoś-Turek, 2018). Jednak ze względu na wysokie koszty, czasochłonność, wymagania sprzętowe i kadrowe (badania zazwyczaj są przeprowadzane w warunkach laboratoryjnych pod opieką specjalnie wykwalifikowanego personelu) testy eyetrackingowe znajdują obecnie wąskie zastosowanie (Klaib et al., 2021), choć dostępne są internetowe narzędzia alternatywne wobec klasycznego okulografu. Jednym $\mathrm{z}$ nich jest oprogramowanie do generowania map cieplnych (ang. heatmaps) za pomocą oprogramowania Hotjar. Umożliwia ono nałożenie na własną stronę nakładki (w postaci skryptu dodawanego do kodu źródłowego), która śledzi zachowania użytkowników na stronie internetowej - nie jest to rejestracja ruchów gałek ocznych użytkowników, ale pełny zapis ruchów ich myszek (przemieszczeń, przesunięć, najechań i kliknięć). Oprócz wygenerowania heatmapy odwzorowującej natężenie kliknięć poszczególnych elementów (Rys. 5, lewy panel), Hotjar rejestruje całą wizytę i ruchy myszki na stronie (Rys. 5, prawy panel). Zapewnia również możliwość podziału wizytujących według krajów oraz rodzaju urządzenia, z którego korzystali przy eksploracji witryny (smarfon, tablet, desktop). Dzięki temu twórcy mają wgląd nie tylko w to, co klikają odbiorcy, ale również jak i w jakiej kolejności to robią oraz której części strony poświęcają najwięcej uwagi, a także mają możliwość oceny korelacji tych danych z lokalizacją użytkownika i wykorzystywanym przez niego urządzeniem.

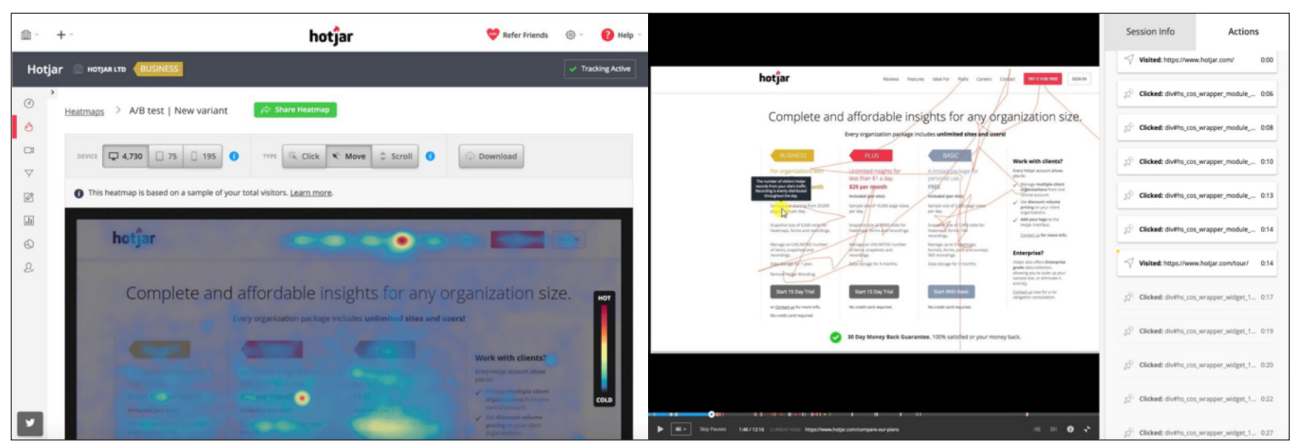

Rys. 5. Zapis ruchów myszki użytkownika i najczęściej klikanych elementów w witrynie na podstawie aplikacji Hotjar (źródło: HotJar https://www.hotjar.com/tour/, dostęp: 3.05.2021) 
Eye-tracking i śledzenie ruchów użytkowników mogą pomóc twórcy w optymalizacji strony internetowej pod względem rozmieszczenia elementów, wyboru ich parametrów i szczegółowości. Pozwalają także twórcy zweryfikować zrozumiałość własnego zamysłu dla użytkownika, intuicyjność interfejsu, nawigację wewnątrz serwisu, funkcjonalność, czy nawet poziom zrozumienia terminologii użytej w etykietach zasobów. Dzięki temu użytkownicy łatwiej będą trafiać w zamierzone miejsce bez zbędnego „skanowania” wszystkich innych treści na stronie (Klaib et al., 2021).

\subsection{Wersje „beta” $i$ crowdtesting}

W fazach testów finalnego produktu jego twórcy mogą opublikować niestabilną jeszcze wersję aplikacji bądź serwisu informacyjnego, która posiada w momencie emisji już pełną lub prawie pełną funkcjonalność, jednak nie jest dogłębnie sprawdzona pod kątem obecności błędów. Wersję taką określa się nazwą beta. Udostępnia się ją wyselekcjonowanej grupie użytkowników lub deweloperów celem weryfikacji założonych funkcjonalności i eliminacji błędów, które mogą pojawić się w większej próbie użytkowników i urządzeń obsługujących aplikację (Jiang et al., 2017).

Crowdtesting nie wymaga od producentów tworzenia formalnego planu badawczego, a jedynie określenia zakładanego czasu crowdsourcowanego testowania i wymagań, które będą weryfikowane przez użytkowników-testerów. Dookreślenia wymagają również metody, według których testujący będą zgłaszać feedback, raportować błędy i kryteria determinujące pozytywną lub negatywną ocenę wyników (Sacha, 2014). Dzięki upublicznieniu wersji testowej swojego produktu producenci oprogramowania mogą zyskać nową, zewnętrzną perspektywę patrzenia na gotowy produkt, poprawić błędy i wzmocnić bezpieczeństwo.

Pośród benefitów wynikających z outsourcowania testowania na użytkowników wymieniane są przede wszystkim: skala (każda osoba z całego świata może wziąć udział w testowaniu), tempo (nieograniczone cyklem dnia i nocy oraz jednej lokalizacji - wynikające wprost z poprzedniego; praca w modelu „24/7”) i, zdeterminowana przez poprzednie punkty, szybkość walidacji testowanego produktu (Roberts, n.d.). Ponadto badana literatura wskazuje na silny związek betatestowania z marketingiem. Produkt jeszcze przed oficjalną premierą staje się widoczny i rozpoznawalny, co przekłada się na ogólny szum wokół przyszłej premiery. Wśród mniej oczywistych benefitów wymieniane jest również „przejście” użytkowników wersji beta do faktycznej usługi. Dzięki temu, twórcy już na starcie docelowej aplikacji, bądź strony WWW mogą posiadać zasobną bazę użytkowników (Jiang et al., 2017).

Z publicznych beta-testów w rozwoju swojego oprogramowania graficznego korzysta np. firma Corel. Zaprasza ona do programu wszystkich zainteresowanych w modelu otwartego zapytania (ang. open-call). Jedynymi warunkami udziału w testowaniu są założenie własnego profilu testera oraz podpisanie klauzuli poufności przekazywanych danych. Po zarejestrowaniu w serwisie użytkownicy uzyskują dostęp do stabilnych beta-wersji aplikacji graficznych i mogą rozpocząć testowanie (Corel, n.d.).

Również firma Apple w swoim „Apple beta software program” umożliwia dostęp do wcześniejszych wersji swoich systemów operacyjnych. W odróżnieniu od Corela, Apple umożliwia dostęp do wersji beta po założeniu przez użytkownika płatnego konta członkowskiego. Program pierwotnie służyć miał deweloperom, aby mogli przystosowywać swoje 
aplikacje do aktualizowanych systemów operacyjnych, jednak obecnie każdy ma możliwość dołączenia do programu i testowania najnowszych rozwiązań (Apple Beta Program, n.d.).

Istnieją także specjalnie dedykowane platformy crowdsourcingowe do testowania stron internetowych i aplikacji. Jedną z nich jest Userfeel, która umożliwia pełną rejestrację interakcji użytkownika z usługą na podstawie przygotowanych scenariuszy z zadaniami (przypominających np. testy użyteczności), według których użytkownik-tester porusza się po witrynie. Userfeel zapisuje zarówno video z ekranu osoby testującej, jak i transkrypcję komentarzy osoby badanej na temat odczuć związanych z produktem (Rys. 6). Pomaga to w szybkiej weryfikacji błędów i analizie danych zebranych od wielu użytkowników zarejestrowanych jako testerzy. Aplikacja zrzesza ponadto testerów, pogrupowanych według znajomości języków i odpowiednio dobiera ich do danego projektu (Userfeel, n.d.).

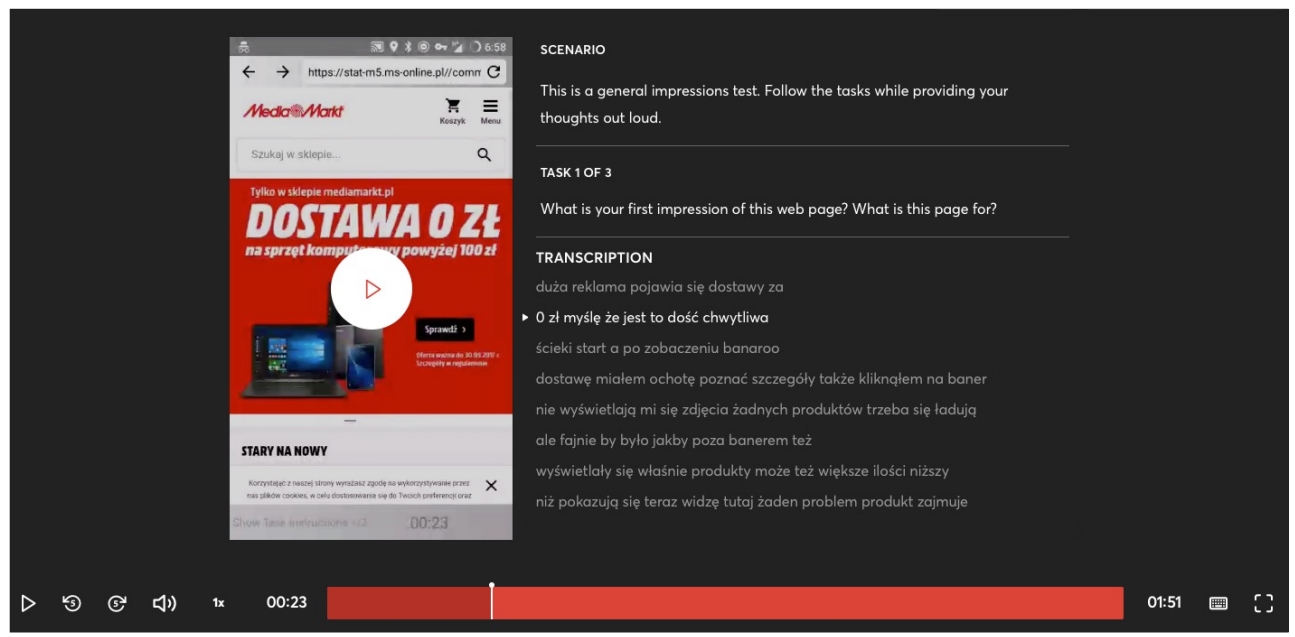

Rys. 6. Zapis wideo testu strony mediamarkt.pl. Po prawej stronie scenariusz, zadania do wykonania i transkrypcja wrażeń użytkownika

(źródło: Userfeel https://app.userfeel.com/result/14c89b8?t=0.1, dostęp: 1.10.2021)

\subsection{Microtasking}

Użytkownicy mogą zostać zaangażowani również do wspomagania walidacji projektów stron WWW lub aplikacji poprzez pomoc w wykonywaniu mniejszych zadań, które są dla komputerów na obecnym etapie rozwoju zbyt skomplikowane lub obarczone dużymi nieprawidłowościami. Microtasking (mikrozadaniowość) polega na podziale większych, złożonych zadań na mniejsze części, dzięki czemu można je powierzyć nieprofesjonalnym indywidualnym użytkownikom (AMT, n.d.). Mikrozadania poprzez Internet mogą być bezproblemowo rozdystrybuowane do dużej liczby odbiorców.

Popularną platformą do zgłaszania zapotrzebowania na mikrozadania jest Amazon Mechanical Turk (AMT). Twórcy mogą zamieszczać na niej ogłoszenia, zaś zarejestrowani użytkownicy otrzymywać wynagrodzenie w zamian za wykonaną pracę (McAllister Byun et al., 2015). Rekrutować można według kryteriów, np. doświadczenia użytkownika 
w innych projektach, jego fizycznej lokalizacji czy rezultatów w testach dopuszczających do uczestnictwa w procesie crowdsourcingu (Assis Neto \& Santos, 2018).

Platformy mikrozadaniowe pozwalają producentom na oszczędzenie czasu, kosztów oraz zasobów poprzez rozłożenie obciążenia na dużą liczbę indywidualnych uczestników. Microtasking często jednak wymaga od twórcy przygotowania platformy, zaplanowania i kontroli całego procesu. Rozwiązanie to najczęściej stosuje się do realizacji prac, w których niezbędna jest ingerencja ludzka - tzw. HIT ${ }^{4}$ (Engine Room, n.d.). Może to być, na przykład, analiza obrazów czy plików audiowizualnych niezrozumiałych dla komputera. Dzięki analizie realizowanej przez użytkowników w modelu mikrozadaniowym twórcy w szybkim tempie mogą udoskonalić lub powiększyć bazę swojej strony internetowej/ aplikacji mobilnej tuż przed przejściem do wdrożenia.

\section{Crowdsourcing na etapie wdrażania oraz dalszego rozwoju}

Po zakończeniu testowania stabilnych wersji produktu oraz implementacji zgłoszonych problemów i nowych rozwiązań, użytkownicy mogą zostać zaangażowani do współpracy na etapie wdrożenia i dalszego rozwijania aplikacji. Etap ten obejmuje wprowadzenie gotowego produktu na rynek i jego dalszą ewaluację. Narzędzia crowdsourcingowe i angażujące użytkownika służyć mogą do pomocy przy konserwacji systemu, dodawaniu funkcjonalności, poprawianiu i unowocześnianiu samego narzędzia (Sikorski, 2010), czy ekspansji na nowe rynki.

\subsection{Zgtaszanie nowych pomysłów i crowdvoting}

Głosowanie jest metodą poznania opinii użytkowników i zaproszenia ich do partycypacji w procesie ewaluacji aplikacji bądź strony internetowej. Poprzez crowdvoting twórcy mogą poznać również potrzeby odbiorców oraz ich oczekiwania wobec produktu. Głosowaniu mogą być poddawane opublikowane przez twórcę innowacje (Majchrzak \& Malhotra, 2013) lub zgłaszane przez społeczność pomysły nowych produktów i rozszerzenia funkcjonalności już istniejących (Hossain \& Islam, 2015). Przykładowo, platforma zakupowa Allegro wprowadziła specjalny serwis spolecznosc.allegro.pl służący zbieraniu pomysłów użytkowników (zarówno kupujących, jak i sprzedających). Nie jest ona jedynie skrzynką odbiorczą, ale funkcjonuje jako ranking, w którym pozostali użytkownicy mogą głosować na zgłoszone udoskonalenia. Umożliwia to Allegro wychwycenie pomysłów najbardziej potrzebnych (Allegro Społeczność, 2020). Serwis zapewnia możliwość skomentowania pomysłu, nie pozostawiając go jedynie do rozpatrzenia, ale dając możliwość jego ewaluacji i klaryfikacji przez społeczność (Rys. 7).

Taka metoda angażowania rozszerza twórcom perspektywę spojrzenia na produkt, daje wgląd w opinie użytkowników, jest kopalnią darmowych pomysłów, i w konsekwencji, pozwala udoskonalić produkt zgodnie z oczekiwaniami odbiorców. Ważnym kryterium przy wyborze pomysłów wykorzystywanych w tworzeniu produktu jest ich wykonywalność (Hossain \& Islam, 2015). W wymienionych wyżej przykładach pochodzących z portalu Allegro,

\footnotetext{
${ }^{4}$ Skrót od: Human Intelligence Task - zadanie wymagające ludzkiej inteligencji.
} 
twórcy postawili na nową zakładkę z zaakceptowanymi pomysłami, aby okazać lojalność wobec udzielającej się społeczności. Allegro stosuje ponadto zakładkę z odrzuconymi usprawnieniami (Rys. 7, panel „Statusy”), chociaż nie umieszcza tam uzasadnienia swojej decyzji. W przypadku zgłaszanych pomysłów, konsekwentny brak realizacji propozycji użytkowników może być źródłem frustracji i zniechęcenia, a w konsekwencji, zaniechania udzielania się na forum społeczności (Blohm et al., 2018).

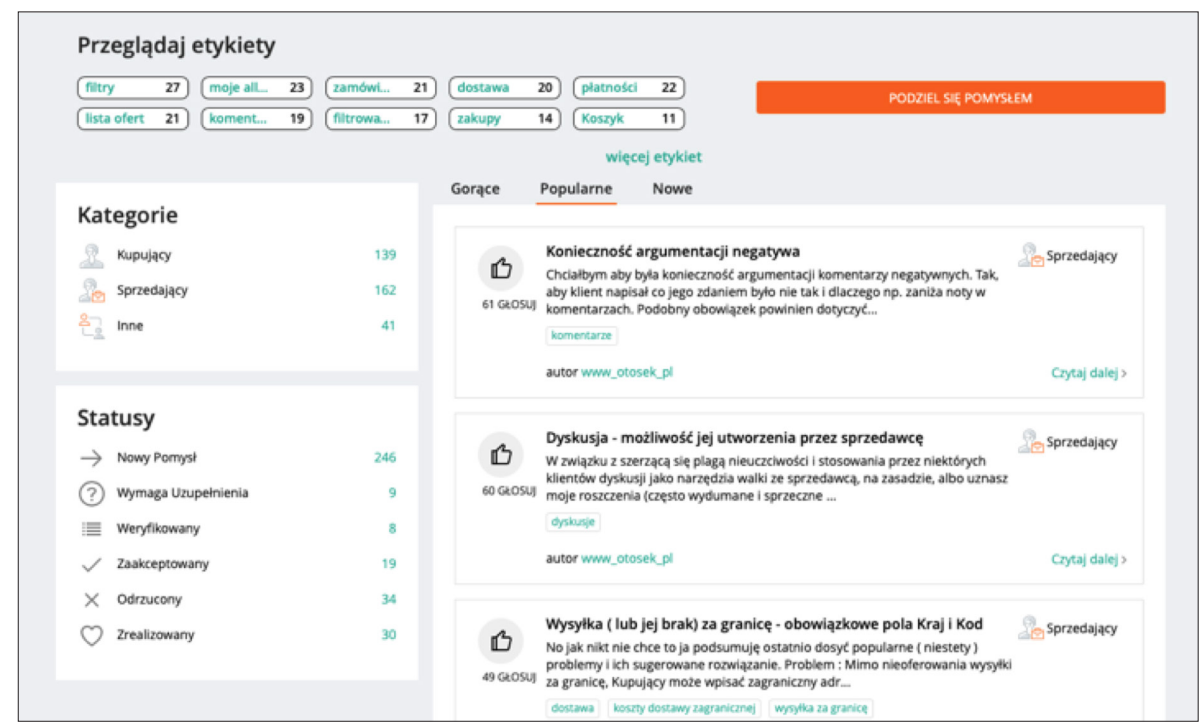

Rys. 7. Ranking pomysłów na usprawnienie platformy zakupowej na podstawie pomysłów użytkowników (źródło: Allegro zgłoś swój pomysł! https://spolecznosc.allegro.pl/t5/zg\%C5\%82o\%C5\%9B-sw\%C3\%B3j-pomys\%C5\%82/idb-p/zglos-pomysl, dostęp: 29.03.2021)

\subsection{Crowdtranslation}

Jeśli twórcy zamierzają skalować i ewaluować stronę internetową bądź aplikację mobilną, aby dostosować ją do innych niż pierwotny/natywny rynek, mogą sięgnąć po narzędzia wspomagające tłumaczenie etykiet zawartych w aplikacjach na inne języki. Pozwala to na szybką ekspansję produktu przy niskim użyciu zasobów finansowych. Zleceniodawcy nie ogranicza żaden język, jedynie liczba aktywnych, natywnie porozumiewających się użytkowników. Nie jest również zobligowany do korzystania z usług translatorów internetowych.

Outsourcowanie tłumaczenia ma jednak wady. Najpoważniejszym niebezpieczeństwem jest utrata jakości w porównaniu do korzystania z usług profesjonalnych tłumaczy - twórca niejako ufa, że społeczność biegle zna język wejściowy (np. angielski) i potrafi przetłumaczyć go precyzyjnie na język ojczysty z uwzględnieniem wszelkich kontekstów, nomenklatury oraz niuansów lingwistycznych (Star, n.d.). Platformy do tłumaczeń open-source, np. Crowdin, proponują połowiczne rozwiązanie problemu poprzez tłumaczenie wspomagane komputerowo (ang. computer-assisted translation). Tekst nie jest tłumaczony wprost, decyzyjność pozostawiona jest tłumaczącemu użytkownikowi, zaś funkcjonalność systemów wspomagania komputerowego obejmuje: rozpoznawanie wzorców, ekstrakcję terminów, narzędzia weryfikacji 
gramatyki i pisowni, słowniki autouzupełniające, bazy terminów etc. Narzędzia te pomagają w utrzymaniu poprawnej składni i gramatyki, prawidłowym rozmieszczeniu słów w porównaniu z oryginałem, czy formatowaniu zgodnym z założeniami aplikacji (Ivanova, 2016) (Rys. 8).

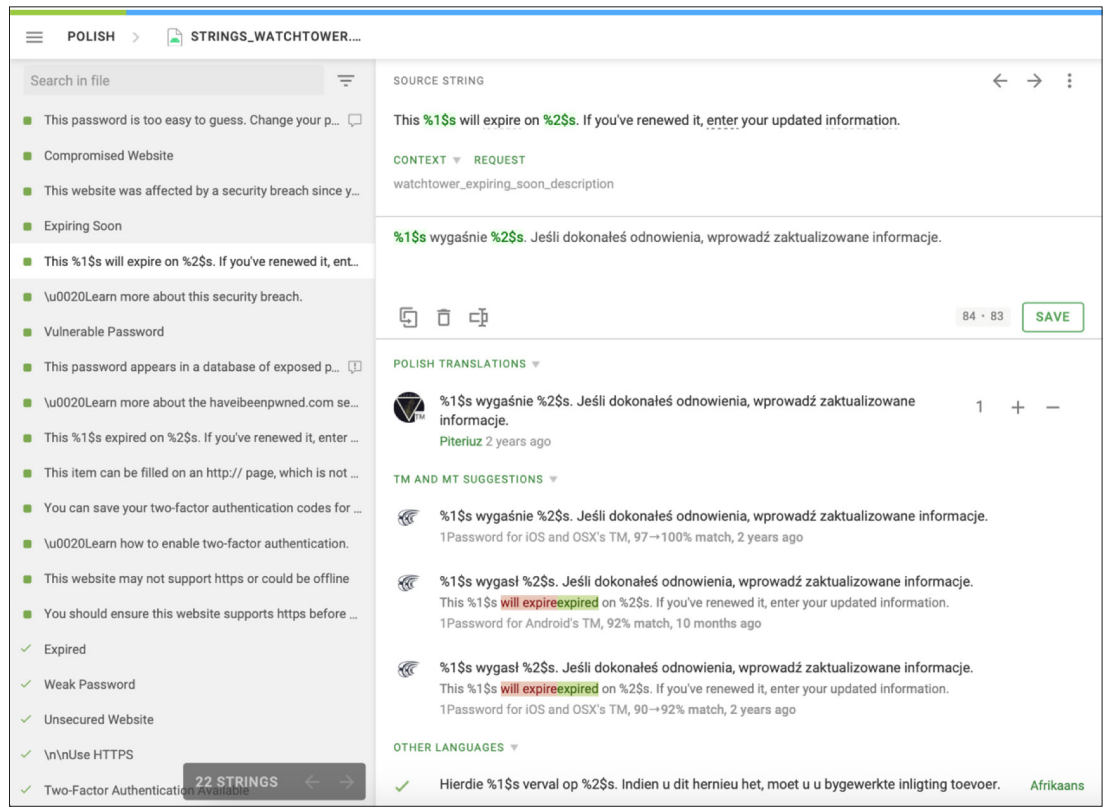

Rys. 8. Panel tłumaczenia etykiet w aplikacji Crowdin dla 1Password, w prawym widoku widać poprawny format składni z kotwicami, licznik znaków, propozycje tłumaczeń innych użytkowników, podpowiedzi tłumaczeń generowane automatycznie oraz tłumaczenia w innych językach (źródło: Crowdin https://crowdin.com/translate/1password-4-for-android/24038/en-pl?filter=basic\&value=0, dostęp: 14.04 .2021 )

Crowdtranslation, w przeciwieństwie do przekładu przez zawodowych tłumaczy, rozwija również społeczne aspekty tłumaczonego serwisu (Ivanova, 2016). Tak jak w przypadku aplikacji Crowdin, tłumacze-wolontariusze mogą wzajemnie moderować i doskonalić swoje tłumaczenie tworząc swoistą giełdę wymiany myśli o aplikacji, jej funkcjonalnościach i dostępności dla użytkowników z danego kraju.

\subsection{Zbieranie feedbacku}

W dwustronnym modelu komunikacji ważnym elementem jest sprzężenie zwrotne, czyli zbieranie informacji o gotowym produkcie od użytkowników. Jego głównym celem jest poznanie opinii użytkowników na temat stworzonej aplikacji bądź strony WWW. Feedback pozwala ponadto określić dysonans między zamierzonymi celami a uzyskiwanymi rezultatami oraz zapewnia możliwość nauki i poprawy błędów (Amonoo et al., 2021; Niepewna, 2018). W przestrzeni współczesnych produktów informacyjnych funkcjonuje najczęściej w postaci krótkich ankiet dotyczących użytych funkcji serwisu (np. procesu zakupowego) bądź nowowprowadzanych funkcjonalności (np. nowych form dostawy). Dzięki takiemu 
rozwiązaniu twórcy mogą uzyskać w krótkim czasie stosunkowo dużą próbę respondentów (Niepewna, 2018). Przykładowo, Allegro pyta, jak udoskonalić nową odroczoną metodę płatności wewnątrz serwisu (Rys. 9), a fintech Revolut rozsyła ankiety dotyczące udostępnianych funkcji grupowych w swojej aplikacji (Rys. 10).

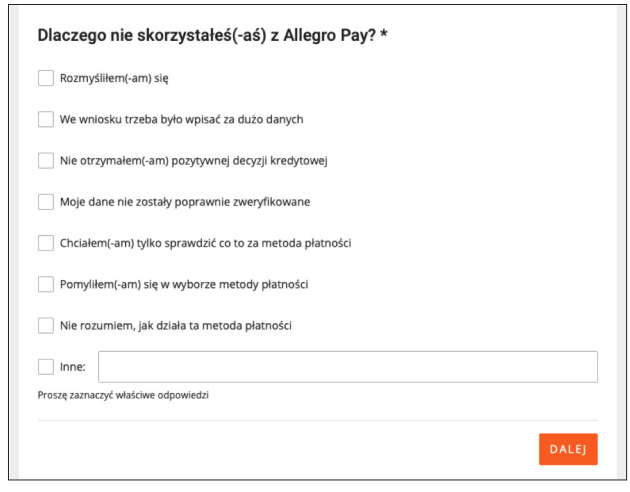

Rys. 9. Ankieta dotycząca usługi AllegroPay

(źródło: Ankiety Allegro https://ankieta. allegro.pl/index.php/235677, dostęp: 1.04.2021)

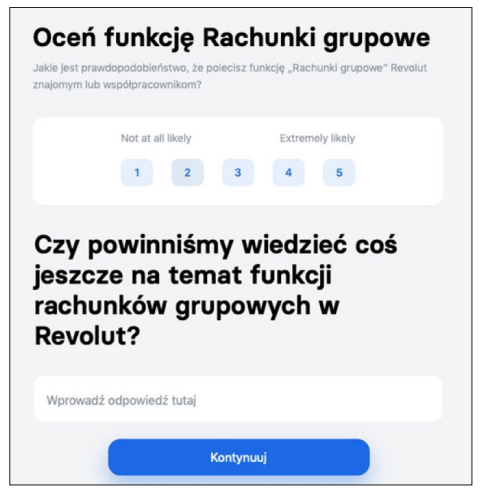

Rys. 10. Ankieta dla użytkowników aplikacji

Revolut dot. rachunków grupowych (źródło: Revolut Forms https://forms.revolut. com/6d9309a5-88d8-4f81-86ca-3f16b09a4cc6?, dostęp: 1.04 .2021$)$

\subsection{Oceny}

Oprócz samego feedbacku twórcy aplikacji lub serwisów internetowych mogą również zwrócić się do użytkowników o pomoc w sprawie oceny oferowanych produktów, treści lub usług. Jest to także specyficzny rodzaj społecznego tagowania - opisanego przez autora szerzej w rozdziale poświęconym etapowi ideacji i prototypowania. Polega on na wystawieniu ocen obiektom umieszczonym na stronie. Mogą być to zarówno oceny przydatności artykułów publicystycznych, jak i złożone opinie o produkcie kupionym w sklepie internetowym. Pomagają one twórcom zrozumieć perspektywę patrzenia przez klienta na doświadczenia związane z oferowaną usługą (np. procesem zakupowym), dostarczają cennych informacji o samym produkcie i determinują powstanie swoistej poczty pantoflowej wśród użytkowników - tzw. eWom ${ }^{5}$ (Xu, 2021). Oceny użytkowników nie muszą być przedstawianie jedynie jako tekstowa recenzja - mogą zostać przetworzone i pokazane np. w postaci uśrednionej lub zamienione na skalę, np. za pomocą gwiazdek (Rys. 11) (Customer Sure, 2021).

Na przykład platforma zakupowa Amazon umożliwia dzielenie się opiniami o oferowanych produktach z wszystkimi użytkownikami serwisu na całym świecie. Oprócz oceny w skali pięciogwiazdkowej możliwe jest dodanie komentarza i opatrzenie recenzji przy pomocy plików zdjęciowych i wideo (Amazon, n.d.). Z kolei platforma Allegro umożliwia również ocenę samego sprzedawcy, czasu realizacji, zgodności produktu z opisem czy

${ }^{5} \mathrm{Z}$ ang. Electronic Word of Mouth - rodzaj nieformalnej komunikacji między użytkownikami za pomocą Internetu, tzw. marketing szeptany. 
ceny przesyłki (Allegro Pomoc, n.d.). Na stronach wsparcia produktów firmy Google po odczytaniu artykułu dostrzec można pytanie, czy dany poradnik był pomocny do wyszukiwanego problemu (Google Support, n.d.).

Dzięki ocenom twórcy zyskują cenną wiedzę o produktach, które oferują. Ułatwia to użytkownikom dokonanie wyboru i uwiarygadnia aukcję na tle innych (sprawia wrażenie sprawdzonej) (Xu, 2021).

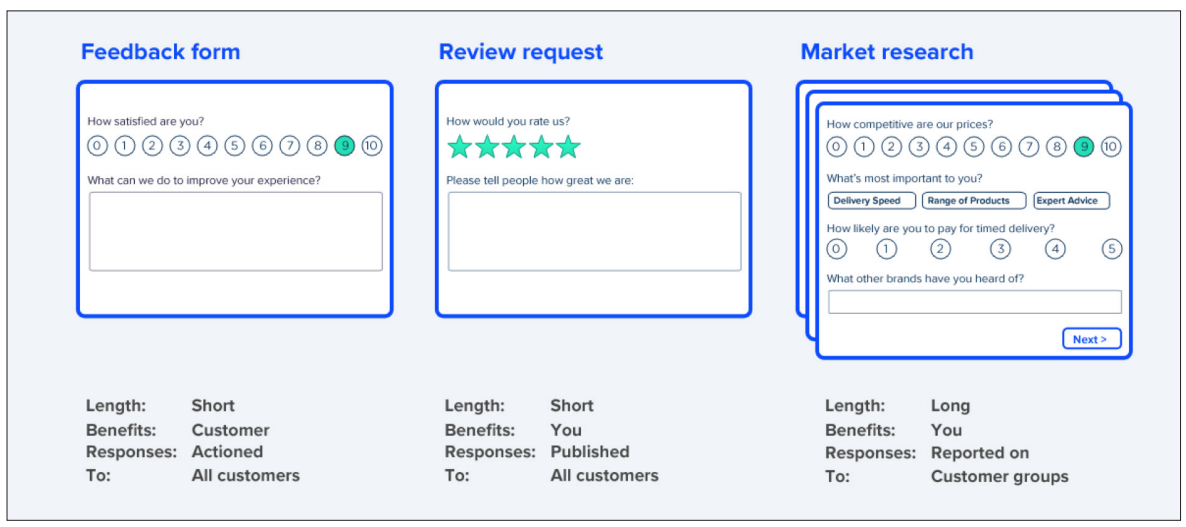

Rys. 11. Przykładowe typy ankiet z ocenami dla użytkowników (źródło: Customer Sure https://www.customersure.com/survey-ratings-scales/, dostęp: 25.04.2021)

\subsection{Hackathony i konkursy}

Formą głębszego angażowania użytkowników, a nawet całych społeczności zgromadzonych wokół produktów informacyjnych, są hackathony. Jest to forma aktywizacji użytkowników w postaci kilkudniowych wydarzeń (zazwyczaj trwających 24 lub 48 godzin), w czasie których uczestnicy mają za zadanie rozwiązać narzucony z góry problem (np. zaprojektowanie jakoś procesu wewnątrz strony internetowej). Dzieleni są na zróżnicowane pod względem zainteresowań zespoły, które rywalizują o miano autora najlepszego rozwiązania. Zwycięzcy mogą otrzymać nagrody, pozyskać dofinansowanie na dalszy rozwój pomysłu oraz zbudować sieć kontaktów (Kvamsas et al., 2021).

Po taką formę zbiorowego czerpania wiedzy sięgnął, na przykład, Bank Pekao SA. Podczas weekendowego hackathonu „\#PekaoCoders” uczestnicy mierzyli się z wyzwaniem, jak analizować dane sprzedażowe pozyskiwane przez terminale płatnicze i do czego można je wykorzystywać (PekaoCoders, 2019). Zadaniem było wykorzystanie danych w celu stworzenia nowego rozwiązania produktowego. Zanim uczestnicy przystąpili do pracy, wzięli udział w warsztatach wstępnych Design Thinking oraz Lean start-up, które pomogły wypracować model przyszłej pracy. Efektami były między innymi aplikacje do przewidywania codziennych wydatków i do oszczędzania dla najmłodszych użytkowników (Gajewski, 2019).

Wśród zalet organizowania przez twórców hackathonów i takiego sposobu angażowania użytkowników wymieniane są:

- $\quad$ innowacje, czyli tworzenie nowych pomysłów i rozwiązań. Dzięki doborowi zróżnicowanej grupy, twórcy otrzymać mogą bogate spektrum punktów widzenia; 
- tworzenie społeczności - zaangażowanie użytkowników we wspólnotę tworzenia;

- zaangażowanie programistów - dzięki hackathonom twórcy mogą nawiązać kontakty z twórcami oprogramowania i społecznościami deweloperów;

- budowa tożsamości marki - promowanie wizerunku produktu otwartego na zewnętrzne wpływy, w tym zdobywanie rozpoznawalności pośród osób związanych $\mathrm{z}$ branżą informatyczną;

- możliwość rekrutacji - umiejętności uczestników mogą być testowane pod względem ewentualnego zatrudnienia (Hackworks, n.d.).

Inną formą angażowania użytkowników mogą być także wszelkiego rodzaju konkursy i zawody, na przykład na wprowadzenie nowej usługi lub udoskonalenie tej istniejącej. Po taką formę crowdsourcowania sięgnęła firma kurierska InPost. Na kanwie tematu dbania o środowisko i promocji ekologicznego stylu życia, ogłosiła konkurs na zaprojektowanie grafik, które docelowo ozdobić mają paczkomaty w całym kraju. Firma udostępniła jedynie siatkę paczkomatu do uzupełnienia w specjalnie do tego stworzonym programie graficznym. W drugim etapie użytkownicy poprzez oddawanie głosów mogli wesprzeć wybrany projekt, który następnie był weryfikowany przez jury (ArtInPost, 2021). Takie rozwiązanie pomaga z jednej strony zaktywizować społeczność (wpłynęło ponad 14 tys. zgłoszeń (InPost, n.d.)), z drugiej zaś - uatrakcyjnić produkt, zdobyć popularność (także jako firma otwarta na prosumpcję) i przyciągnąć nowych klientów.

\section{Wnioski}

Jak pokazują omówione przez autora metody angażowania użytkowników w procesie projektowania, crowdsourcing realizowany za pomocą platform internetowych sprawdza się obecnie w sytuacjach, w których twórcy nie znają pełnego kontekstu działania aplikacji - potencjalnych odbiorców, potrzeb, efektów, środowiska itp. Dlatego użytkowników angażuje się najczęściej w zakresie doskonalenia aplikacji przez bezpośredni lub pośredni wybór najlepszych rozwiązań proponowanych przez twórców, czy poprzez sugerowanie własnych. Użytkownicy znający swoje indywidualne wymagania wobec produktu są pomocni także w ocenie efektywności, funkcjonalności czy wyglądu. Dzięki temu produkt nie zatrzymuje się w czasie, jest nieustannie modernizowany.

Crowdsourcing staje się pomocny również tam, gdzie zadania do wykonania są rozdrobnione i słabo ze sobą powiązane - jak na przykład w przypadku tłumaczenia etykiet i wykonywania mikrozadań. Dzięki zaangażowaniu wielu indywidulnych „pracowników-wolontariuszy" zadania takie wykonywane są szybciej i taniej. Efekt masowości może być także pomocny w szybkim wychwytywaniu błędów (np. po aktualizacji), dzięki czemu twórcy mogą szybko reagować na niespodziewane sytuacje.

Skutkiem niejako ubocznym zaangażowania użytkowników jest również popularyzacja serwisu czy też aplikacji w społeczeństwie. Klienci potrzebują mniej czasu na znalezienie informacji na temat produktu, gdyż treści generowane są nie tylko przez twórców, ale i przez zaangażowanych użytkowników (w postaci np. postów na forach czy tutoriali). Produkt zbiera także dużo opinii, które są widoczne dla innych i uwiarygadniają jego wizerunek. To wszystko wydaje się odgrywać znaczącą rolę w budowaniu pozytywnego odbioru marki i przyciąganiu kolejnych użytkowników - co warto poddać odrębnym badaniom. 
Jednak są także obszary procesu projektowania obecnie niezagospodarowane przez crowdsourcing. Użytkownicy w procesie projektowym są angażowani głównie do walidacji. Poza drobnymi wyjątkami w postaci hackathonów, stoją zazwyczaj na końcu łańcucha wytwórczego - sprawdzają, porównują, oceniają. Ich wiedzę stosuje się raczej do przetwarzania i weryfikowania pomysłów twórców, niż faktycznego projektowania i wytwarzania gotowych rozwiązań.

Zatem polem crowdsourcingowo niezagospodarowanym pozostaje sam proces wytwarzania stosownego oprogramowania - począwszy od tworzenia prototypów, przez opracowywanie kodu źródłowego, na kreacji interfejsu graficznego skończywszy. Twórcy na etapach poprzedzających faktyczną implementację rzadko sięgają po gotowe rozwiązania opracowane przez użytkowników - częściej, jak pokazano w artykule, dzieje się to na tych etapach procesu projektowania, gdy produkt lub usługa znajduje się już na rynku. W przypadku tego rodzaju działalności crowdsourcingowej, zaangażowani użytkownicy musieliby cechować się zapewne określonym zestawem umiejętności - podobnie jak jest to w przypadku uczestnictwa w hackathonach.

Jednak, pomimo tego, że obecnie potencjał użytkowników nie jest wykorzystywany w obszarach związanych z wymienionymi wyżej etapami wytwarzania aplikacji bądź serwisu, miłośnicy marek i produktów już teraz dzielą się między sobą, wewnątrz społeczności, amatorskimi projektami przyszłych rozwiązań zarówno software’owych jak i hardware'owych - tzw. conceptami. Są to wizualizacje przyszłych produktów lub projekty graficzne przyszłego oprogramowania wytwarzane zazwyczaj na podstawie plotek i domysłów związanych z daną marką oraz jej linią produktową, publikowane wewnątrz społeczności dla zobrazowania pomysłu na implementację tych produktów w rzeczywistości (Arif, 2021; Kozerawski, 2014). Przykładowo, fani konsol do gier video tworzą amatorskie mockupy przyszłych wersji modeli z serii PlayStation (PS5Home, n.d.), zaś przywoływana już społeczność zgromadzona wokół firmy Apple dzieli się pomysłami na nowe rozwiązania, które mogłyby być zaimplementowane w przyszłych wersjach systemów operacyjnych (Cult of Mac, n.d.; MacRumours, n.d.). Popularnym miejscem zamieszczania amatorskich conceptów jest serwis YouTube, na którym w maju 2021 r. znaleźć można było kilka tysięcy filmów z amatorskimi koncepcjami konsol od Sony oraz tzw. renderów conceptów systemu iOS.

W kontekście tworzenia stron internetowych i aplikacji mobilnych krystalizuje się także nisza w obszarze tzw. crowdsourced design - czyli platform z otwartymi "zleceniami” dla projektantów-freelancerów, z szerokiego spektrum dziedzin (np. retuszowanie zdjęć, projektowanie logotypów czy okładek książek, tworzenie sloganów itp.). Choć jest to obecnie jeden z najsłabiej zbadanych obszarów w obrębie crowdsourcingu, który dopiero obecnie zaczyna się rozwijać (Aliady \& Alyahya, 2018), twórcy za pomocą takiego rodzaju platform crowdsourcingowych mogą już teraz zlecać tworzenie elementów graficznych swoich przyszłych produktów informacyjnych - stron internetowych i aplikacji mobilnych. Projektowanie to może realizować się w trzech obszarach:

(1) tworzenia interfejsów - „tłum” ma za zadanie stworzyć interfejs graficzny aplikacji, bądź strony internetowych w oparciu o zestaw wytycznych, szablonów i potencjalnych ograniczeń;

(2) projektowania architektury systemu - zadaniem jest stworzenie architektury danego systemu na podstawie specyfikacji wybranej przez instytucję zlecającą;

(3) rewizji projektów - zadaniem użytkowników jest weryfikacja zaproponowanych projektów, celem ich udoskonalenia (Mao et al., 2017).

Proces jest inicjowany na platformie przez podmiot zlecający/pomysłodawcę $\mathrm{w}$ formie zapytania do wybranej grupy zarejestrowanych użytkowników. Ponadto wyznacza budżet, 
zakres i termin wykonania zadania. Następnie użytkownicy nadsyłają swoje propozycje i między sobą decydują w formie głosowania, które z projektów są najlepsze. Te z kolei, są analizowane przez inicjatora kampanii (Aliady \& Alyahya, 2018, za: Li et al., 2016).

Pośród największych zalet takiego podejścia do projektowania, wymieniana jest możliwość swoistej „personalizacji” produktu według potrzeb grupy, która go projektuje oraz szeroki wachlarz inspiracji dla twórców, którzy mogą wybrać spośród wielu propozycji. Natomiast wadą takiego rozwiązania jest liniowość crowdsourcowanego designu - projekt zostaje poddany ocenie dopiero, gdy osiągnie swą pełną formę (La Toza et al., 2015), nie ma możliwości wyboru np. pewnego elementu interfejsu i połączenia go z pracą innego użytkownika.

Przykładami platform, które obecnie zapewniają możliwość crowdsourced designu są: Crowdspring, 99Designs, czy CrowdSite. Platformy te pozwalają łączyć twórców z użytkownikami, którzy chcieliby spróbować swoich sił w projektowaniu. Twórcy mają możliwość zamieścić własne ogłoszenia z zapotrzebowaniem na projekt interfejsu, logotypu, elementów wizualnych itp., ale i projektanci mogą publikować właśnie portfolio z dotychczasowymi realizacjami. CrowdSite umożliwia także komunikację zleceniodawcy z projektantem jeszcze na etapie projektowania, co może być pomocne przy płynnej weryfikacji pomysłów. Jednak wszystkie z wymienionych platform działają we wspomnianym wyżej modelu linearnym, w którym użytkownicy nie mogą współpracować i dzielić się przemyśleniami na etapie samego procesu projektowania (a jedynie po opublikowaniu pełnego projektu) (Aliady \& Alyahya, 2018; Araujo, 2013; Crowdspring, n.d.), co może być także luką do przyszłego zagospodarowania.

Przytoczone przykłady obrazują poziom i skalę zjawiska, które niewielkim kosztem może zostać w niedalekiej przyszłości przekute na proces crowdsourcowania gotowych pomysłów i wymianę rozwiązań w postaci np. łączenia gotowych elementów interfejsów, rozwiązań funkcjonalnych, czy nawet poszczególnych linii kodu języka programowania. Możliwości zaangażowania użytkowników wydają się być tak samo nieskończone jak nieskończony jest proces tworzenia współczesnego produktu informacyjnego. Autor wskazał powyżej jedynie przykład przyszłego zastosowania crowdsourcingu, jednak nieustannie pojawiają się kolejne metody, inne ewoluują by powrócić w zupełnie innej formie (jak w przypadku eye-trackingu).

W społecznościach zgromadzonych wokół produktów drzemie ogrom pomysłów, które odpowiednio zaimplementowane, mogą przyczynić się do ich poprawy. Poprzez rozwiązania oferowane przez platformy crowdsourcingowe, twórcy są w stanie niewielkimi nakładami zaangażować społeczność do współtworzenia treści i partycypacji w procesie tworzenia aplikacji mobilnych i stron internetowych. Nie mniej ważny jest fakt, że pozytywne efekty współpracy nie są jednostronne. Również i prosumenci czerpią wymierne korzyści z zaangażowania używana aplikacja bądź serwis internetowy są aktualniejsze, bardziej niezawodne, dostępne i dostosowane do otaczającej rzeczywistości (jak w przypadku tłumaczeń). Użytkownicy, oprócz wspólnej prosumpcji, mają poczucie realnego wpływu na produkt, współtworzenia go i dzielenia się nim z innymi. Jednym ze skutków crowdsourcingu jest także nawiązanie specyficznej relacji pomiędzy użytkownikami oraz pomiędzy użytkownikami i twórcami. Marka i jej produkty nie są już autonomicznymi, odległymi bytami, ale stają się współtworzonym konstruktem z rozproszoną grupą odbiorców wnoszących swój wkład w jego powstanie i rozwój.

Jednakże najważniejsze jest to, że ze wszystkich podmiotów najwięcej na tej współpracy zyskuje sam produkt - serwis informacyjny czy aplikacja mobilna. Nieustannie aktualizowany, dostosowywany i dopracowywany dzięki partnerstwu, staje się diamentem nieprzerwanie szlifowanym wspólnie po obu stronach rondysty. 


\section{Bibliografia}

Afuah, A., Tucci, C. L. (2012). Crowdsourcing as a Solution to Distant Search. Academy of Management Review, 37(3), 355-375. https://doi.org/10.5465/amr.2010.0146

Aliady, R., Alyahya, S. (2018). Crowdsourced Software Design Platforms: Critical Assessment. Journal of Computer Science, 14(4), 546-561. https://doi.org/10.3844/jcssp.2018.546.561

Allegro Pomoc (n.d.). Pomoc dla kupujacych: jak ocenić zakup? [online]. Allegro Pomoc [1.04.2021], https://allegro.pl/pomoc/dla-kupujacych/oceny-i-komentarze/jak-ocenic-zakup-mGwAg1LxPFW

Allegro Społeczność (2020). Zgtaszajcie swoje pomysty! [online]. Allegro Gadane [8.02.2021], https:// spolecznosc.allegro.pl/t5/zgłoś-swój-pomysł/zgłaszajcie-swoje-pomysły/idi-p/82450

Amazon (n.d.). Customer Reviews [online]. Amazon Help \& Customer Service [11.05.2021], https:// www.amazon.com/gp/help/customer/display.html/ref=hp_left_v4_sib?ie=UTF8\&nodeId=G3UA5WC5S5UUKB5G

Amonoo, H. L., Longley, R. M., Robinson, D. M. (2021). Giving Feedback. Psychiatric Clinics of North America. https://doi.org/10.1016/j.psc.2020.12.006

AMT (n.d.). Amazon Mechanical Turk Overview [online]. MTurk [15.04.2021], https://www.mturk.com

App Store Preview (n.d.). Forza Football - Live Scores [online]. App Store [2.03.2021], https://apps. apple.com/pl/app/forza-football/id500138120

Apple Beta Program (n.d.). Apple Developer Program Overview [online]. Apple Developer [10.12.2020], https://developer.apple.com/programs/

Araujo, R. M. (2013). 99designs : An Analysis of Creative Competition in Crowdsourced Design. First AAAI Conference on Human Computation and Crowdsourcing, (May), 17-24.

Arif, S. (2021). Forget PS5: This Stunning Sony PlayStation Phone Concept Is What We Want [online]. Tom's Guide [25.05.2021], https://www.tomsguide.com/news/sony-ps5g-phone-concept-isstunning-and-the-perfect-ps-vita-successor

ArtInPost. (2021). Zasady ArtInPost: Edycja 2021 [online]. ArtInPost [13.05.2021], https://artinpost. $\mathrm{pl} /$ \#zasady

Assis Neto, F. R., Santos, C. A. S. (2018). Understanding Crowdsourcing Projects: A Systematic Review of Tendencies, Workflow, and Quality Management. Information Processing and Management, 54(4), 490-506. https://doi.org/10.1016/j.ipm.2018.03.006

Badura, C. (2019). UXUI. Design Zoptymalizowany. Gliwice: Helion.

Bar-Ilan, J., Zhitomirsky-Geffet, M., Miller, Y., Shoham, S. (2013). The Effects of Background Information and Social Interaction on Image Tagging. Journal of the American Society for Information Science and Technology, 64(July), 1852-1863. https://doi.org/10.1002/asi.21306

Blohm, I., Zogaj, S., Bretschneider, U., Leimeister, J. M. (2018). How to Manage Crowdsourcing Platforms Effectively? California Management Review, 60(2), 122-149. https://doi.org/10.1177/0008125617738255

Choosing a Business Model. (n.d.). Retrieved April 15, 2020, from https://developer.apple.com/app-store/business-models/

Corel (n.d.). Firma Corel szuka testerów wersji beta! [online]. Corel [1.05.2021], https://www.corel. $\mathrm{com} / \mathrm{pl} /$ pages/beta/

Crowdspring (n.d.). How It Works? [online] Crowdspring [29.09.2021], https://www.crowdspring. com/how-it-works/

Cult of Mac (n.d.) Tagged: iOS 14 Concept [online], Cult of Mac [25.05.2021], https://www.cultofmac. com/tag/ios-14-concept/

Customer Sure (2021) What's the Best Rating Scale to Use on a Customer Service Survey? [online]. Customer Sure [14.05.2020], https://www.customersure.com/survey-ratings-scales/

Dzikowska, J. (2016). Miliony na biznes ze zrzutki w sieci - tu każdy może być inwestorem [online]. Wyborcza.biz [30.03.2021], https://wyborcza.biz/biznes/1,147584,20080524,w-sieci-kazdy-moze-byc-inwestorem.html 
Engine Room (n.d.). Microtasking Definition [online]. The Engine Room's Library [15.04.2021], https:// library.theengineroom.org/microtasking/

Estellés, E., González, F. (2012). Towards an Integrated Crowdsourcing Definition. Journal of Information Science, (X), 1-22. https://doi.org/10.1177/016555150000000

Forza Football (n.d.). Forza Football Advertising [online]. Forza Football [12.12.2020], https://forzafootball.com/company/advertising/

Gajewski, M. (2019). Co bank może zrobić dla ciebie? Możliwości eksplorowali najambitniejsi ze studentów [online]. Spider's Web [13.05.2021], https://spidersweb.pl/2019/12/pekao-hackatonfinal.html

Gerber, E., Hui, J., Kuo, P.-Y. (2012). Crowdfunding: Why People are Motivated to Post and Fund Projects on Crowdfunding Platforms. Computer Supported Cooperative Work 2012, Workshop on Design Influence and Social Technologies: Techniques, Impacts and Ethics, Seattle, WA. (Vol. 10).

Google Support (n.d.). Jak możemy pomóc? [online]. Google Support [12.05.2021], https://support. google.com $/$ ?hl=pl

Hackworks (n.d.). Benefits of Hackathons [online]. Hackworks [13.05.2021], https://www.hackworks. com/en/benefits

Hossain, M., Islam, K. M. Z. (2015). Generating Ideas on Online Platforms: A Case Study of "My Starbucks Idea." Arab Economic and Business Journal, 10(2), 102-111. https://doi.org/10.1016/j. aebj.2015.09.001

InPost (5.05.2021). ArtInPost: Ogłaszamy laureatów (aktualizacja statusu w serwisie Facebook), https://www.facebook.com/paczkomaty/posts/10159108071462999

Ivanova, O. (2016). Translation and ICT Competence in the Globalized World. Procedia - Social and Behavioral Sciences, 231(May), 129-134. https://doi.org/10.1016/j.sbspro.2016.09.081

Jiang, Z., Scheibe, K. P., Nilakanta, S., Qu, X. S. (2017). The Economics of Public Beta Testing. Decision Sciences, 48(1), 150-175. https://doi.org/10.1111/deci.12221

Keyser, P. de. (2012). Indexing: From Thesauri to the Semantic Web. Oxford: Chandos Publishing.

Kickstarter (2015). BeeLine - Smart Navigation For Bicycles, Made Simple [online]. Kickstarter [13.04.2021], https://www.kickstarter.com/projects/ridebeeline/beeline-smart-navigation-forbicycles-made-simple

Klaib, A. F., Alsrehin, N. O., Melhem, W. Y., Bashtawi, H. O., Magableh, A. A. (2021). Eye Tracking Algorithms, Techniques, Tools, and Applications With an Emphasis on Machine Learning and Internet of Things Technologies. Expert Systems With Applications, 166(September 2020), 114037. https://doi.org/10.1016/j.eswa.2020.114037

Kowalska, M. (2015). Crowdsourcing internetowy. Poztytwny wymiar partycypacji społecznej. Warszawa: Wydawnictwo SBP.

Kozerawski, K. (2014). Kolejny koncept $i$ Watcha. Jak to jest $z$ wizjami niezależnych projektantów [online]. MyApple [25.05.2021], https://myapple.pl/posts/5005-kolejny-koncept-iwatcha-jak-tojest-z-wizjami-niezaleznych-projektantow

Krętowski, M. (n.d.). UPEDU: Implementacja [29.04.2021], http://aragorn.pb.bialystok.pl/ mkret/ Lectures/io2_08.pdf

Kvamsås, H., Neby, S., Haarstad, H., Stiller-Reeve, M., Schrage, J. (2021). Using Collaborative Hackathons to Coproduce Knowledge on Local Climate Adaptation Governance. Current Research in Environmental Sustainability, 3, 100023. https://doi.org/10.1016/j.crsust.2020.100023

La Toza, T. D., Chen, M., Jiang, L., Zhao, M., Van Der Hoek, A. (2015). Borrowing From the Crowd: A Study of Recombination in Software Design Competitions. Proceedings - International Conference on Software Engineering, 1(March), 551-562. https://doi.org/10.1109/ICSE.2015.72

Lawrence, A., Schneider, J. (2018). This is Service Design Doing. Sebastopol: O'Reillly Media.

MacRumours (n.d). Concepts Articles [online]. MacRumors [25.05.2021], https://www.macrumors. com/guide/concepts/ 
Majchrzak, A., Malhotra, A. (2013). Towards an Information Systems Perspective and Research Agenda on Crowdsourcing For Innovation. Journal of Strategic Information Systems, 22(4), 257-268. https://doi.org/10.1016/j.jsis.2013.07.004

Mao, K., Capra, L., Harman, M., Jia, Y. (2017). A Survey of the Use of Crowdsourcing in Software Engineering. Journal of Systems and Software (Vol. 126). https://doi.org/10.1016/j.jss. 2016.09.015

McAllister Byun, T., Halpin, P. F., Szeredi, D. (2015). Online Crowdsourcing for Efficient Rating of Speech: A Validation Study. Journal of Communication Disorders, 53, 70-83. https://doi.org/10.1016/j.jcomdis.2014.11.003

MindSea (2020). Mobile App Pricing Strategies [online]. Mindsea [12.12.2020], https://mindsea.com/ mobile-app-pricing-strategies/

Mościchowska, I., Rogoś-Turek, B. (2018). Badania jako podstawa projektowania User Experience. Warszawa: Wydawnictwo Naukowe PWN.

Mount, M., Round, H., Pitsis, T. S. (2020). Design Thinking Inspired Crowdsourcing: Toward a Generative Model of Complex Problem Solving. California Management Review, 62(3), 103-120.

Niedzielska, A. (2017). Marketing angażujący w Internecie i aplikacjach mobilnych. Engagement Marketing on the Internet and Mobile Apps., (5), 298-308.

Niepewna, U. (2018). Feedback - czym jest i dlaczego warto go zbierać [online]. Webankieta [20.02.2021], https://blog.webankieta.pl/feedback/

PekaoCoders (2019). Hackathon \#PekaoCoders - jak zastosować big data w bankowości? [online]. Bank Pekao: Biuro Prasowe [2.03.2021], https://media.pekao.com.pl/pr/419703/hackathon-pekaocodersjak-zastosowac-big-data-w-bankowosci

Phyo, A. (2003). Web Design. Projektowanie atrakcyjnych stron WWW. Gliwice: Helion.

PitchBook (n.d.). BeeLine Valuation \& Funding [online]. PitchBook [20.02.2021], https://pitchbook. com/profiles/company/152510-95\#funding

PS5Home (n.d.). PS5 Concepts [online]. PS5Home [26.05.2021], https://www.ps5home.com/ps5-concepts/

Roberts, N. (n.d.). What is Crowdsourced Testing? [online]. Global App Testing [3.10.2021], https:// www.globalapptesting.com/blog/crowdsourced-testing https://www.globalapptesting.com/blog/ crowdsourced-testing

Rosenfeld, L., Morville, P., Arango, J. (2017). Architektura informacji w serwisach internetowych i nie tylko. Gliwice: Helion.

Roszkowski, M. (2007). Folksonomia jako narzędzie społecznego tagowania. Warsztaty Bibliotekarskie, $4(24)$.

Sacha, K. (2014). Inżynieria oprogramowania. Warszawa: Wydawnictwo Naukowe PWN.

Seedrs (2017). Beeline - Smart navigation made simple. A vision to make journeys better for everyone [online]. Seedrs [13.04.2021], https://www.seedrs.com/beeline2/sections/idea

Shapiro, C., Varian, H. (2007). Potega informacji. Gliwice: Helion.

Sikorski, M. (2010). Interakcja człowiek-komputer. Warszawa: Wydawnictwo PJWSTK.

Star (n.d.). Crowd Translation [online]. Star [8.02.2021], https://www.star-ts.com/translation-faq/ what-is-crowd-translation/

Tan, Y. H., Reddy, S. K. (2021). Crowdfunding Digital Platforms: Backer Networks and Their Impact on Project Outcomes. Social Networks, 64, 158-172. https://doi.org/10.1016/j.socnet.2020.09.005

Userfeel (n.d). Customer FAQ [online]. Userfeel [3.10.2021] https://www.userfeel.com/faq

Xu, X. (2021). Closed-Form Evaluations and Open-Ended Comment Options: How Do They Affect Customer Online Review Behavior and Reflect Satisfaction With Hotels? Decision Support Systems, 145(February), 113525. https://doi.org/10.1016/j.dss.2021.113525

Yasar, B. (2021). The New Investment Landscape: Equity Crowdfunding. Central Bank Review, 21(1), 1-16. https://doi.org/10.1016/j.cbrev.2021.01.001 
YLAI (2016). Crowdfunding: The Power of People [online]. Young Leaders of Americas Initiative [10.03.2021], https://ylai.state.gov/crowdfunding-power-people/

Zhang, Y., Tan, C. D., Sun, J., Yang, Z. (2020). Why Do People Patronize Donation-Based Crowdfunding Platforms? An Activity Perspective of Critical Success Factors. Computers in Human Behavior, 112. https://doi.org/10.1016/j.chb.2020.106470

\title{
Crowdsourcing Platforms: a Tool for User Engagement in the Process of Designing Websites and Mobile Applications
}

\begin{abstract}
Purpose/Thesis: The aim of this paper is to analyze and discuss crowdsourcing tools used at each stage of website and mobile application design processes. The objective was to identify and develop methods for increasing user participation, and to present effects of the collaboration between users and creators.

Approach/Methods: As a result of the dynamic nature of crowdsourcing itself, specific techniques of engaging users were identified by the author on the basis of a comprehensive literature analysis which encompassed scientific and professional articles, discipline-specific textbooks and commercial reports. As crowdsourcing platforms are practical tools, the paper examines particular cases of implementation.

Results and conclusions: Crowdsourcing tools are used at every stage of the design process - they provide inspiration and offer more economically profitable solutions. However, they mostly yield unstructured suggestions, reaffirming previously implemented solutions. Crowdsourcing is hardly ever used in development of digital tools. However, the author has identified cases of user engagement in these processes, which may in future take the form of crowdsourcing.

Originality/Value: According to the author's knowledge, similar studies have not yet been conducted in either Polish or international scholarship and thus the paper is the very first attempt of a holistic analysis and classification of individual crowdsourcing tools.
\end{abstract}

Keywords

Crowdsourcing. Crowdsourcing platforms. Customer engagement. Design process. Mobile applications. User centered design. User engagement. Web services. Websites.

ANDRZEJ GIL jest absolwentem studiów I stopnia na kierunku Architektura przestrzeni informacyjnych na Uniwersytecie Warszawskim. Obecnie jest studentem studiów II stopnia na kierunkach: Zarzadzanie Big Data na Uniwersytecie Warszawskim oraz Informatyka na specjalizacji Informatyka Społeczna w Polsko-Japońskiej Akademii Technik Komputerowych. Niniejszy artykuł napisany zostat na podstawie pracy licencjackiej pod tytutem Crowdsourcing w procesie projektowania serwisów informacyjnych i aplikacji mobilnych oraz stanowi debiut autora w piśmiennictwie naukowym.

Kontakt $z$ autorem:

andrzej@gheell.com

Wydziat Dziennikarstwa, Informacji i Bibliologii

Uniwersytet Warszawski

ul. Nowy Świat 69

00-046 Warszawa 